\title{
LINK AND MATCH PENDIDIKAN SEKOLAH KEJURUAN
}

\author{
Muh Turizal Husein \\ abiturizal68@gmail.com \\ (Dosen Fakultas Agama Islam, Universitas Muhammadiyah Tangerang)
}

\begin{abstract}
Abstrak:
Penelitian ini bertujuan untuk mengetahui model kerja sama link and match yang efektif untuk diterapkan guna meningkatkan kesiapan kerja bagi lulusan Sekolah Menengah Kejuruan (SMK). Dibutuhkan suatu kebijakan yang dapat meningkatkan relevansi antara Sekolah Kejuruan dengan Dunia Usaha dan Dunia Industri. Jenis penelitian ini adalah penelitian studi kasus (case study) dengan menggunakan metode penelitian kualitatif. Penelitian ini melakukan studi kasus di SMK Muhammadiyah 1 Cipondoh Kota Tangerang Jurusan Bisnis Manajemen Kompetensi Keahlian Akuntansi bertujuan untuk mempelajari secara intensif mengenai latar belakang masalah pengangguran dan bagaimana kebijakan link and match dapat menjadi solusi mengatasi pengangguran. Penetapan informan sebagai sumber data menggunakan teknik purposive sampling dan pengumpulan data menggunakan teknik wawancara mendalam, observasi dan dokumentasi. Hasil penelitian menunjukkan bahwa (1) dengan adanya link and match antara pemasok tenaga kerja dengan penggunanya Pendidikan Kejuruan dapat mengetahui kompetensi (keahlian) apa yang paling dibutuhkan dunia kerja (2) model kerja sama link and match dikatakan efektif bilamana model kerja sama link and match mengantarkan standar kompetensi lulusan SMK sama dengan kompetensi harapan DUDI.
\end{abstract}

\section{Kata Kunci: Pengangguran, Link and Match, Pendidikan Kejuruan}

\section{A. Pendahuluan}

Hubungan antara dunia pendidikan dan dunia industri yang sering disebut link and match $^{l}$ sampai saat ini masih menyisahkan permasalahan. Berbagai upaya untuk menjaga relevansi antara pendidikan dan industri tidak tepat jika hanya dimaknai sekedar mentransfer teknologi dan ketrampilan khusus yang digunakan dunia industri ke lembaga pendidikan. Link and match harus dimaknai sebagai upaya lembaga

\footnotetext{
${ }^{1}$ Djojonegoro, Wardiman. Sepanjang Jalan Kenangan. (Jakarta : KPG, 2016), hlm, 288. Istilah link and match saat ini cukup banyak diperbincangkan dalam dunia pendidikan. Konsep ini digagas oleh Menteri Pendidikan dan Kebudayaan Republik Indonesia tahun 1993-1998, Prof. Dr.-Ing. Wardiman Djojonegoro. Link secara harfiah berarti ada pertautan atau hubungan interaktif dan match berarti cocok. artinya link and match adalah adanya keterkaitan dan kesepadanan dengan kebutuhan dan permintaan (needs, demands)
}

pendidikan dalam menyiapkan tenaga kerja yang mempunyai kemampuan berpikir, berkomunikasi, berinteraksi sosial, dan bekerja secara kelompok.

Sekolah Menengah Kejuruan yang diharapkan dapat menjadi jembatan link and match karena memiliki dual system education ternyata juga belum memenuhi harapan. Masih banyak outcome SMK yang belum terserap dunia kerja. Rendahnya outcome lulusan SMK tersebut bukan mutlak karena tidak adanya lapangan kerja, tetapi diantaranya karena rendahnya kompetensi lulusan. Banyak lowongan kerja yang tersedia tidak terisi karena lulusan SMK tidak memenuhi persyaratan kompetensi yang dibutuhkan dunia kerja. Banyak ditemukan diantara lulusan yang bekerja, tidak sesuai dengan bidang kompetensi yang siswa pelajari. Beberapa perusahaan yang masih peduli dan memanfaatkan lulusan SMK, sebagian besar menempatkan lulusan SMK bekerja 
di pos yang tidak sesuai jurusan, seperti menjadi penjaga took, satpam perumahan, atau tempat lainnya yang tidak sesuai dengan bidang keahliannya..

Merujuk hasil survey Badan Pusat Staistik Provinsi Banten Tahun 2015, angka tingkat pengangguran terbuka di Provinsi Banten bisa dikatakan cukup tinggi. Tingginya angka tersebut menandakan bahwa tingkat keterserapan tenaga kerja di sana cukup rendah. Berdasarkan hasil tersebut terindikasi bahwa tingkat pengangguran terbuka dari segala jenjang pendidikan masih tergolong tinggi di Provinsi Banten. Sehingga dapat disimpulkan bahwa Angkatan kerja bila dikaitkan dengan pendidikan SMP dan SMA sederajat sepertinya sulit untuk mendapatkan pekerjaan karena harus bersaing dengan angkatan kerja berpendidikan SD dalam mendapatkan pekerjaan tanpa kualifikasi pendidikan.

\section{Tabel 1.1}

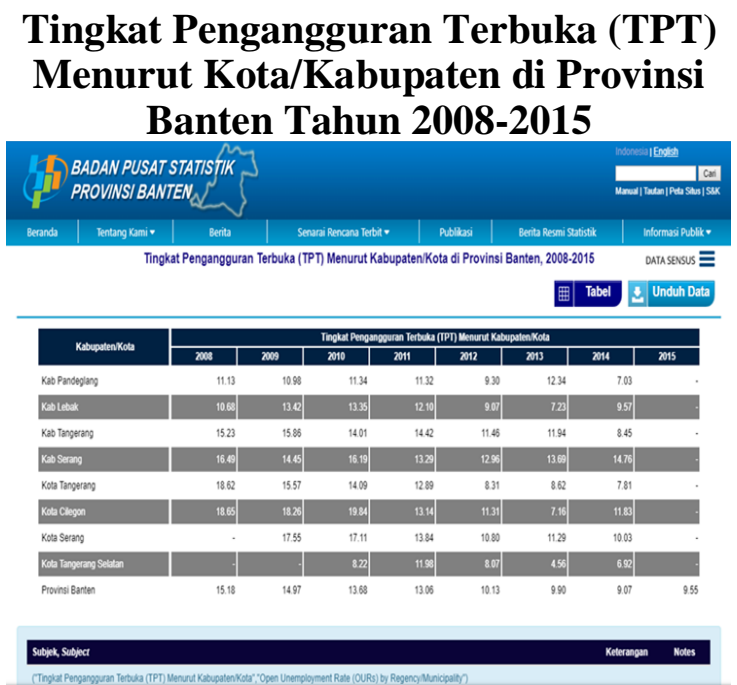

Sumber: Badan Pusat Statistik Provinsi Banten, 2015

Selanjutnya merekapun kalah bersaing dengan angkatan kerja yang mempunyai pendidikan lebih tinggi. Tingkat pengangguran terbuka pada SMK tergolong yang tertinggi dari jenjang pendidikan lainnya sebesar 10.69 dari total angkatan kerja yang tersedia yaitu sebesar 519.56 ribu orang ribu orang yang terdiri dari 355, 28 ribu orang $(68,38$ persen $)$ lakilaki dan 164,29 ribu orang (31,62 persen) perempuan. Persentase penduduk yang menganggur dari seluruh angkatan kerja sebesar 9,28 persen. Bila dibandingkan dengan tahun sebelumnya, penduduk yang menganggur naik sebesar 0,36 poin $^{2}$.

Masalah pengangguran seharusnya tidak terjadi pada lulusan SMK. Sekolah menengah kejuruan menekankan pada persiapan anak didik untuk memasuki dunia kerja dengan berbekal keterampilan yang didapatkan dari proses pembelajaran praktik.Keterampilan yang dipelajari di pendidikan formal tidak sepenuhnya dapat digunakan didunia kerja. Missmatch ini terjadi karena dimana terjadinya ketidakcocokan antara bidang studi dengan kebutuhan dunia kerja.

Ini tantangan besar yang harus dihadapi pemerintah dalam upaya menciptakan lapangan kerja sesuai dengan kompetensi yang dibutuhkan Dunia Usaha dan Dunia Industri yang relevansinya menyangkut dua dimensi yaitu, sekolah dan dunia kerja atau masyarakat. Masalah tingginya angka pengangguran di Provinsi Banten tidak terkecuali di Kota Tangerang salahsatunya disebabkan oleh manajemen pendidikan yang kurang baik atau lulusan dan outcomenya tidak memiliki kompetensi yang sesuai dengan kebutuhan pasar atau dunia kerja. Seperti kebutuhan tenaga kerja bidang kemaritiman, pertanian, industry kreatif dan pariwisata.

Konsep keterkaitan dan kesepadanan (Link and Match) saat ini, antara dunia

\footnotetext{
${ }^{2}$ Keadaan Angkatan Kerja Provinsi Banten Agustus 2017, The unemployed population in 2017 was 519,56 thousand people consisting of 355,28 thousand people $(68,38$ percent) of male and 164,29 thousand people (31,62 percent) of female. The percentage of the unemployed population of the entire labor force was 9,28 percent. Compared with the previous year, the unemployed population increased by 0.36 points. The highest education of the unemployed population at most senior high school graduates, that is 250,28 thousand people or about 48,17 percent of total unemployed population. In addition, 41,71 thousand people or 8,03 percent of unemployed are intellect unemployed that graduates over high school.
} 
pendidikan dan Industri sangatlah ideal, apabila ada hubungan timbal balik yang dilakukan, antara pemasok tenaga kerja yaitu SMK dengan penggunanya yaitu dunia kerja. Dengan adanya hubungan timbal balik ini membuat SMK dengan mudah dapat menyusun kurikulum sesuai dengan kebutuhan dunia kerja. Pada hakekatnya menjalankan link and match bukanlah hal yang sederhana dan mudah, olek karena itu idealnya ada tiga komponen yang harus bergerak simultan untuk menyukseskan program link and match yaitu SMK selaku pemasok tenaga siap pakai, dunia kerja (perusahaan) selaku pengguna jasa dan pemerintah yang memiliki kebijakan dan aturan. Dari ketiga komponen tersebut, peran SMK merupakan keharusan dan syarat terpenting. Kreativitas dan kecerdasan pengelola SMK dibawah komando seorang Kepala Sekolah menjadi faktor penentu bagi sukses tidaknya program tersebut. Ada beberapa langkah penting yang harus dilakukan SMK untuk menyukseskan program link and match. SMK harus mau melakukan riset ke dunia kerja. Tujuannya adalah untuk mengetahui kompentensi (keahlian) apa yang paling dibutuhkan dunia kerja dan kompetensi apa yang paling banyak dibutuhkan dunia kerja. Selain itu, SMK juga harus mampu memprediksi dan mengantisipasi keahlian (kompetensi) apa yang diperlukan dunia kerja dan teknologi lima atau sepuluh tahun kedepan.

Jika program link and match berjalan baik, pemerintah juga diuntungkan dengan berkurangnya beban pengangguran (terdidik). Artinya, ${ }^{3}$ pengangguran terdidik adalah mereka yang memiliki latar belakang pendidikan akademik yang cukup tinggi, namun tidak terserap oleh pasar kerja. Hal ini menunjukkan indikasi kurang selarasnya perencanaan pembangunan

\footnotetext{
${ }^{3}$ Purwaka Hari Prihanto, Tren dan Determinan Pengangguran Terdidik di Provinsi Jambi. Jurnal Paradigma Ekonomika 2012. Vol. 1 No. 5.
}

pendidikan dan perkembangan lapangan kerja, sehingga lulusan institusi pendidikan tidak terserap ke lapangan kerja. Karena itu, seyogyanya pemerintah secara serius menjaga iklim keterkaitan dan mekanisme implementasi ilmu dari SMK ke dunia kerja sehingga diharapkan program link and match ini berjalan semakin baik dan semakin mampu membawa manfaat bagi semua pihak. Contoh nyata link and match ini adalah program kerjasama dengan Dunia Usaha/Industri, pengembangan kelas industri, pelaksanaan guru magang (OJT), Prakerin, dan Peran SMK sebagai hubungan industri bagi sekolah lain.

\section{B. Metode Penelitian}

Penelitian ini menggunakan metode penelitian kualitatif dengan menggunakan pendekatan studi kasus (case study). Lokasi penelitian ini dilakukan di SMK Muhammadiyah 1 Cipondoh Kota Tangerang, Jurusan Bisnis Manajemen Kompetensi Keahlian Akuntansi. Penetapan informan sebagai sumber data menggunakan teknik purposive sampling. Pengumpulan data menggunakan metode kualitatif dilakukan dengan wawancara mendalam, observasi dan dokumentasi untuk mengembangkan model kerja sama link and match untuk meningkatkan kesiapan kerja, Analisis data kualitatif: reduksi data, paparan data, dan penarikan kesimpulan data. Pendekatan studi kasus merupakan penelitian analisis deskriptif, yang mana penelitiannya berfokus pada suatu kasus tertentu yang diamati dan dianalisis secara cermat. Penelitian ini memusatkan diri terhadap kebijakan model link and match dan mempelajarinya sebagai suatu kasus dalam menanggulangi masalah pengangguran.

\section{Hasil Dan Pembahasan}

Model Kebijakan Link and Match Antara Dunia Pendidikan dan Dunia Kerja

Program link and match saat ini cukup banyak diperbincangkan dalam 
dunia pendidikan. Konsep ini digagas oleh Menteri Pendidikan dan Kebudayaan Republik Indonesia tahun 1993-1998, Prof. Dr.-Ing. Wardiman Djojonegoro. Link secara harfiah berarti ada pertautan atau hubungan interaktif dan match berarti cocok. artinya link and match adalah adanya keterkaitan dan kesepadanan dengan kebutuhan dan permintaan (needs, demands). Kebutuhan dalam pembangunan sangat luas, multidimensional dan multisektoral. Mulai kebutuhan peserta didik sendiri, kebutuhan keluarganya, kebutuhan untuk pembinaan masyarakat dan warga negara yang baik, hingga kebutuhan dunia kerja. Namun demikian data dilapangan menunjukkan masih tingginya angka pengangguran, tingginya lowongan kerja yang tidak terisi dan rendahnya kualitas pekerja. Ini menunjukkan bahwa masih terdapat missmacth antara pendidikan dan dunia kerja. Missmatch antara pendidikan dan dunia kerja secara tidak langsung akan mengakibatkan tingkat pendapatan yang lebih rendah, rendahnya kepuasan kerja, dan tingginya tingkat turn over pekerja, yang pada akhirnya mempengaruhi produktivitas kerja. ${ }^{4}$ Rendahnya tingkat pendapatan menurut penulis akan membuka lebar jurang kemiskinan dan kebodohan.

Selanjutnya Mcgowan \& Andrew, menjelaskan dengan terjadinya missmatch akan memberikan pengaruh yang relevan terhadap efesinsi investasi pendidikan karena mempengaruhi upah dan keluaran serta hasil tenaga kerja lainnya. Seperti kepuasan kerja dan turn over pekerja. Semua ini jika tidak mendapatkan perhatian serius oleh pemasok kerja dan pemerintah, akan mempengaruhi

${ }^{4}$ Mcgowan, M.A \& Andrew, D. (2015).The Future of Productivity: Main Background Paper Labour Market Missmatch and Labour Productivity: Evidence From Piaac Data: Economic Departement Working Papers No. 1209, 27 (1),151 keunggulan dan kebijakan pembangunan ekonomi suatu daerah.

Sebagai contoh dari penelitian Ivan Putranto (2017) Berdasarkan studi pendahuluan yang dilaksanakan di Kota Semarang pada beberapa siswa SMK Bisnis Manajemen kelas XII Kompetensi Akuntansi dengan cara penyebaran angket secara acak dan terwakilkan setiap akreditasi baik akreditasi A, B maupun C, dari 56 angket diperoleh bahwa 6 siswa atau $10,17 \%$ siswa dalam kategori kesiapan kerja rendah, 36 siswa atau $61,01 \%$ siswa memiliki kesiapan kerja dalam kategori sedang, dan $28,81 \%$ siswa dalam kategori kesiapan kerja tinggi. Dalam hal ini kesiapan kerja siswa SMK kelas XII Akuntansi di Kota Semarang masih belum optimal.

Belum optimalnya kesiapan kerja siswa SMK bisnis manajemen kompetensi akuntansi di Kota Semarang seharusnya tidak terjadi, mengingat tujuan SMK untuk mempersiapkan peserta didik terutama untuk bekerja dalam bidang tertentu (UU No. 20 Tahun 2003), sesuai kebutuhan DUDI melalui kebijakan pemerintah dalam menerapkan pembelajaran SMK melalui konsep link and match. Konsep link and match ini merubah pembelajaran yang berbasis sekolah menjadi pembelajaran berbasis ganda, dimana dalam pembelajaran di SMK dilaksanakan di dua tempat yaitu di sekolah dan di lingkungan DUDI. Pembelajaran di sekolah berupa teori dan praktik dasar kejuruan, sementara pada lingkungan DUDI pembelajaran diperoleh melalui prinsip learning by doing yaitu berupa keterampilan produktif.

Berdasarkan hasil observasi pendahuluan diatas dan didukung oleh data yang didapat di SMK Muhammadiyah 1

${ }^{5}$ Iva.n Putranto, (2017), Pengembangan Model Kerja Sama Link and Match Untuk Meningkatkan Kesiapan Kerja Bagi Lulusan SMK Kompetensi Keahlian Akuntansi di Kota Semarang. J. Mandiri., Vol. 1, No. 1, Juni 2017 (69 - 83) (C2017 Lembaga Kajian Demokrasi dan Pemberdayaan Masyarakat (LKD-PM) 
Cipondoh Kota Tangerang, kendala yang didapat dalam mengimplementasi Program link and match di Provinsi Banten khususnya terdapat beberapa permasalahan diantaranya. Pertama, masalah pembangunan insfrastruktur belajar mengajar, sebagai contoh masih minimnya SMK Jurusan Pariwisata,kimia, baja dan otomotif ${ }^{6}$. Untuk Jurusan Pariwisata, Banten memiliki potensi pariwisata yang tidak kalah menariknya dengan Pariwisata yang dimiliki daerah lain. Akibat dari minimnya jurusan yang sesuai dengan kebutuhan pasar kerja di Banten mengakibatkan ada beberapa SMK di Banten yang paling banyak melahirkan pengangguran, diantaranya, komunikasi, computer dan multimedia.Kedua, masalah kurikulum kurang sesuai dengan kondisi daerah. Contoh daerah Lebak dan Pandeglang lebih sesuai dibuka jurusan Pariwisata dan Pertanian dari pada jurusan multimedia. Ketiga, kurangnya koordinasi diantara stakeholders terkait, masih berjalan parsial. Harus ada saling kerjasama seperti koordinasi pihak perusahan dengan pendidikan dalam menyususn kurikulum, biar sesuai dengan kebutuhan pasar. Keempat, belum maksimalnya pemetaan kebutuhan tenaga kerja, berapa kualifikasi tenaga kerja tertentu yang dibutuhkan atau kualifikasi tenaga kerja yang seperti apa yang benar benar dibutuhkan.Kelima, terbatasnya lowongan kerja bagi lulusan SMA, ini terjadi dunia kerja banyak yang memperkerjakan lulusan SMA dibanding lulusan SMK, padahal mereka tidak memiliki keahlian dalam bidang pekerjaannya. Keenam, banyak lulusan SMK yang bekerja diluar dari keahlian yang dimiliki, karena minimnya lapangan kerja.

Dari hasil penelitian diatas dapat dikatakan bahwa pemerintah harus bekerja ekstra dalam menanggulangi permasalahan

${ }^{6}$ https://www.radarbanten.co.id. Rabu 20 Desember 2017, diakses 10 Mei 2019 pengangguran. Ada dua fokus yang harus segera dibenahi oleh pemerintah khususnya Pemerintah Provinsi Banten yaitu fokus pertama, Sumber Daya, meliputi Sumber Daya Manusia dan Sumber Daya Alamnya serta fokus keduanya yaitu sisi sosialnya. Dengan terfokusnya dua perhatian pemerintah laksanakan akan mempermudah model link and match antara penyedia tenaga kerja (supply) dengan permintaan tenaga kerja (demand) terlaksana. Akan mudah mengahasilkan outcome lulusan yang memiliki kualifikasi sesuai dengan kebutuhan dunia kerja, baik dilihat dari kualitas maupun kuantitas.

\section{Urgensi Model Kebijakan Link and Match Dalam Pendidikan}

Direktorat PSMK menyatakan bahwa

Sekolah Menengah Kejuruan (SMK) merupakan lembaga pendidikan yang berperan untuk menyiapkan peserta didik menjadi tenaga kerja tingkat menengah untuk membantu pembangunan sektor perekonomian bangsa. Melalui Instruksi Presiden (Inpres) Nomor 9 Tahun 2016 tentang Revitalisasi Sekolah Menengah Kejuruan (SMK/MAK), ${ }^{7}$ dunia pendidikan sangat terbantu karena akan terciptanya link and match antar instansi dan lembaga terkait sesuai dengan tugas dan fungsi masing masing dalam usaha mengangkat kualitas SMK/MAK. Dengan terciptanya model link and match antara dunia pendidikan dan dunia kerja diharapkan dapat menekan angka pengangguran yang disumbang lulusan sekolah kejuruan.

Dengan diberlakukannya Masyarakat Ekonomi Asean (MEA) mulai akhir tahun 2015, memungkinkan adanya peningkatan mobilitas dan persaingan tenaga kerja secara bebas antara anggota Negara Asean. Diperkirakan pada tahun 2010 hingga tahun 2025 permintaan akan pekerja terampil di kawasan ASEAN akan

\footnotetext{
${ }^{7}$ Republik Indonesia, 2016. Inpres Nomor 9 tentang Revitalisasi SMK
} 
mengalami kenaikan sekitar $41 \%$ atau sekitar 14 juta orang, dan separuh dari jumlah tersebut merupakan kebutuhan tenaga kerja Indonesia. Oleh karena itu untuk menjawab tantangan MEA dalam menciptakan tenaga terampil dan memenuhi permintaan sekitatar separuh dari 14 juta pekerja di kawasan ASEAN adalah menerapkan kebijakan link and match merupakan keharusan dan tidak boleh ditunda tunda, sehingga nantinya bisda menjawab tantangan tersebut. Paling tidak harus ada terciptanya link and match antara pemangku kepentingan yaitu Pendidikan Kejuruan dan Perguruan Tinggi di satu sisi dan Dunia Kerja (perusahaan) serta Pemerintah disisi lain. Jika ini berjalan dengan baik semua komponen yang terlibat didalamnya akan mendapatkan keuntungan dengan berkurangnya beban angka pengangguran. Berkurangnya angka pengangguran secara otomatis akan menaikkan tingkat pendapatan dan kesejahteraan masyarakat, dan ini akan menjadi dasar majunya suatu Bangsa.

\section{Strategi Model kebijakan Sekolah Kejuruan}

Sebuah strategi agar dapat di implementasikan secara baik dan benar diperlukan suatu analisis yang mendalam. Beberapa strategi yang menjadi focus dalam mewujudkan kebijakan link and match adalah :

\section{Pendekatan Sosial}

Menurut Usman pendekatan sosial adalah pendekatan yang didasarkan atas keperluan masyarakat pada saat ini. Pendekatan ini menitikberatkan pada tujuan pendidikan dan pada pemerataan dalam kesempatan mendapatkan pendidikan. ${ }^{8}$ Sebagai contoh penerapan pendekatan ini adalah diterapkan SMK Model melalui kebijakan link and match.

\footnotetext{
${ }^{8}$ Usman, H. Manajemen: Teori, Praktek dan Riset Pendidikan, (Jakarta: Bumi Aksara, 2012), h. 56
}

\begin{tabular}{ccr} 
SMK & Model & \multicolumn{2}{c}{ merupakan } \\
pengembangan & dari & SMK yang
\end{tabular} menyelenggarakan fungsi tunggal yaitu menyiapkan peserta didik untuk memasuki lapangan kerja pada bidang tertentu menjadi SMK yang menyelenggarakan multi-fungsi (fungsi majemuk) atas dasar prinsip-prinsip kemanfaatan, keterpaduan program, integrasi sumber daya (manusia, uang, peralatan, bahan, dan sebagainya), resource sharing, dan pemanfaatan teknologi informasi dan komunikasi secara maksimal. SMK Model dituntut untuk menjadi sekolah cerdas (kreatif, inovatif, inisiatif, cepat, tepat, dan cekat) dalam mengembangkan program-programnya, dan memiliki keunggulan-keunggulan dibanding dengan SMK-SMK lain dalam inputnya (kurikulum, guru, fasilitas, dan sebagainya), prosesnya (pembelajaran, manajemen, kepemimpinan, dan sebagainya), dan outputnya (mutu lulusan dan mutu produk-produk lain yang dihasilkan). Satu hal mendasar yang harus dilakukan oleh SMK Model adalah membangun kerjasama, kolaborasi, dan sinergi dengan dunia kerja, mulai dari perumusan kompetensi, penyusunan bahan ajar, pelaksanaan kegiatan, hingga sampai evaluasi dan sertifikasi kompetensi.

Program-program di SMK Model disusun selaras dengan kebutuhan peserta didik dan kemajemukan kebutuhan masyarakat serta dunia kerja dalam berbagai sektor dan sub-sub sektornya, baik sektor primer, sekunder, tersier maupun kuarter. Oleh karena itu, keselarasan antara SMK Model dan dunia kerja merupakan imperatif, baik dalam dimensi kuantitas (jumlah), kualitas (kompetensi), lokasi (tempat), maupun waktu (kapan). SMK Model dapat menyelenggarakan beragam jalur pendidikan, baik formal maupun nonformal, selaras dengan kebutuhan masyarakat lokal, nasional, regional, dan internasional. Oleh karena itu, berbagai alternatif jalur, jenis, dan jenjang pendidikan yang selaras dengan 
kebutuhan-kebutuhan tersebut harus disediakan melalui program-program yang berpihak kepada kemajemukan kebutuhan masyarakat.

\section{Pendekatan Sumber Daya Manusia}

Pendekatan Sumber Daya Manusia disini lebih menitikberatkan pada pendekatan ketenagakerjaan. Didalam pendekatan ini pendidikan lebih diarahkan kepada usaha-usaha untuk memenuhi kebutuhan tenaga kerja, tenaga kerja yang memiliki kualifikasi sesuai dengan yang dibutuhkan dunia kerja (perusahaan). Dalam kondisi ini setiap Negara mengharapkan supaya pendidikan mempersiapkan dan menghasilkan outcome lulusan yang terampil dan memiliki kualifikasi yang sesuai dengan kebutuhan dunia kerja.Baik sektor pertanian, perdagangan, industry dan lain sebagainya. Untuk itu SMK Model dituntut untuk mengembangkan program-program berdasarkan keunggulan local, berdasarkan karakteristik dan kebutuhan Banten karena Provinsi muda ini memiliki kekayaan alam yang beragam dan melimpah serta kemajemukan sektor-sektor pembangunan, baik sektor primer (pertanian, perkebunan, peternakan, perikanan/kelautan, dan sebagainya.), sektor sekunder (industri, perusahaan), sektor tersier/jasa langsung (bank, transportasi), maupun sektor kuarter/jasa tidak langsung (konsultan, penasehat, dan sebagainya). Siswa SMK harus berjati diri Indonesia yang ditempuh melalui pendidikan kewarganegaraan.

Kedua pendekatan diatas akan mudah berjalan apabila strategi yang akan diakan dijalankan benar-benar di kawal dan diimplementasikan pada semua tingkatan.Adapun sterategi effektif tersebut adalah: ${ }^{9}$

${ }^{9}$ Soesilowati, E.S. Link and Match Dunia Pendidikan dan Industri Dalam Meningkatkan Daya Saing Tenaga Kerja dan Industri. (Jakarta: Lipi Press, 2009).
1) Perlu dikaji dan ditata kembali berbagai produk hukum baik UndangUndang Peraturan Pemerintah, Keputusan Presiden, Keputusan Menteri sebagai paying hukum link and match antara dunia Pendidikan dan Pendidikan Tinggi dan Dunia Industri.

2) Perlu ditentukan lagi institusi otoritas link and match baru selain yang sudah ada seperti Dirjen Dikti atau Kadin.

3) Perlu dirinci tugas dan fungi institusi serta mekanisme kerjanya yang lebih terukur, terutama menyangkut penyusunan kurikulum, program magang, riset, penyusunan road map sektoral dan regional alokasi lowongan kerja dan rencana predeksi kedepan.

4) Strategi lainnya adalah penegakan low enforment agar semua aktivitas perbaikan link and match sesuai perintah Undang-Undang.

5) Untuk mengurangi akses supply tenaga kerja berpendidikan tinggi perlu kebijakan yang dikeluarkan pemerintah untuk perluasan industri-industri baru.

\section{Kesimpulan}

Link and match sebagai model kebijakan pendidikan kejuruan adalah suatu penilaian terhadap system nilai dan faktor-faktor kebutuhan situasional lembaga pendidikan, untuk dijadikan panduan dalam mengambil suatu kebijakan dalam bingkai keputusaan bersama agar tujuan pendidikan yang dicita-citakan dapat terlaksana. Keputusan dalam bentuk kebijakan (policy marking). Model kebijakan pendidikan kejuruan dalam bentuk link and match merupakan konsep keterkaitan antara lembaga pendidikan dengan dunia kerja. Dengan adanya keterkaitan antara lembaga pendidikan dengan dunia kerja maka akan terjalin kerjasama agar siswa bisa magang atau melakukan peraktek kerja di perusahaan tersebut. Apabila model ini dapat dijalankan secara berkelanjutan Pendidikan Kejuruan dapat dengan mudah mengetahui 
kompetensi keahlian apa yang paling banyak dibutuhkan oleh Perusahaan.

Adapun strategi yang menjadi fokus dalam mewujudkan kebijakan link and match adalah pendekatan social dan pendekatan Sumber Daya Manusia, dalam hal ini pendekatan ketenagakerjaan. Pendekatan sosial didasarkan atas keperluan masyarakat pada saat ini. Pendekatan ini menitikberatkan pada tujuan pendidikan dan pada pemerataan dalam kesempatan mendapatkan pendidikan. Sebagai contoh penerapan pendekatan ini adalah diterapkan SMK Model melalui kebijakan link and match.

SMK Model dianggap sebagai penentu keberhasilan sebagai pemasok tenaga kerja yang siap pakai di dunia kerja, karena dianggap bagian dari pengembangan dari SMK yang menyelenggarakan fungsi tunggal yaitu menyiapkan peserta didik untuk memasuki lapangan kerja pada bidang tertentu menjadi SMK yang menyelenggarakan multi-fungsi (fungsi majemuk) atas dasar prinsip-prinsip kemanfaatan, keterpaduan program, integrasi sumber daya (manusia, uang, peralatan, bahan, dan sebagainya), resource sharing, dan pemanfaatan teknologi informasi dan komunikasi secara maksimal.

Selama ini antara dunia pendidikan, pemerintah dan perusahaan telah banyak menjalankan program link and match, namun karena upaya tersebut kurang komprehensif, konsisten dan berkelanjutan serta tidak adanya payung hukum yang jelas, maka segala upaya yang dilakukan oleh banyak pihak tidak berjalan dengan baik. Oleh karena itu menyusun strategi jangka panjang masih perlu dilakukan dengan melibat seluruh stakeholder mulai dari tingkat Provinsi sampai dengan Kota Kabupaten. Keputusan dalam bentuk policy marking sangat ideal dalam mengawal kebijakan yang akan diterapkan di lapangan.

\section{DAFTAR PUSTAKA}

Djojonegoro, Wardiman. Sepanjang Jalan Kenangan. (Jakarta : KPG, 2016)

BPS Provinsi Banten, Keadaan Angkatan Kerja Provinsi Banten Bulan Agustus 2017

Purwaka Hari Prihanto, Tren dan Determinan Pengangguran Terdidik di Provinsi Jambi. Jurnal Paradigma Ekonomika 2012. Vol. 1 No.5.

Mcgowan, M.A \& Andrew, D. (2015).The Future of Productivity: Main Background Paper Labour Market Missmatch and Labour Productivity: Evidence From Piaac Data: Economic Departement Working Papers No. 1209,27 (1),1-51

Iva.n Putranto, (2017), Pengembangan Model Kerja Sama Link and Match Untuk Meningkatkan Kesiapan Kerja Bagi Lulusan SMK Kompetensi Keahlian Akuntansi di Kota Semarang. J. Mandiri., Vol. 1, No. 1, Juni 2017 (69 - 83) @2017 Lembaga Kajian Demokrasi dan Pemberdayaan Masyarakat (LKD$P M)$

https://www.radarbanten.co.id. Rabu 20 Desember 2017, diakses 10 Mei 2019

Republik Indonesia, 2016. Inpres Nomor.9 tentang Revitalisasi SMK

Usman, H. Manajemen: Teori, Praktek dan Riset Pendidikan, (Jakarta: Bumi Aksara, 2012)

Soesilowati, E.S. Link and Match Dunia Pendidikan dan Industri Dalam Meningkatkan Daya Saing Tenaga Kerja dan Industri. (Jakarta: Lipi Press, 2009). 
Rausyan Fikr. Vol. 15 No. 2 September 2019. ISSN. 1979-0074 e-ISSN. 9772580594187 | 62 